\title{
Article \\ Colorimetric Aptasensor for Detecting Bacillus carboniphilus Using Aptamer Isolated with a Non-SELEX-Based Method
}

\author{
Ho-Kyeong Kim ${ }^{1,2}$, Hye-Ri Kim ${ }^{1,3}$, Su-Jin Yoon ${ }^{3,4}$, Kang-Bong Lee ${ }^{3,4}$, Jungbae Kim ${ }^{2, *}$ \\ and Byoung-Chan Kim 1,3,*(D) \\ 1 Center for Environment, Health and Welfare Research, Korea Institute of Science and Technology (KIST), \\ Seoul 02792, Korea; khk1123@gmail.com (H.-K.K.); h17014@kist.re.kr (H.-R.K.) \\ 2 Department of Chemical and Biological Engineering, Korea University, Seoul 02841, Korea \\ 3 Division of Energy and Environment Technology, KIST School, University of Science and Technology (UST), \\ Seoul 02792, Korea; h20017@kist.re.kr (S.-J.Y.); leekb@kist.re.kr (K.-B.L.) \\ 4 National Agenda Research Division, Korea Institute of Science \& Technology (KIST), Seoul 02792, Korea \\ * Correspondence: jbkim3@korea.ac.kr (J.K.); bchankim@kist.re.kr (B.-C.K.)
}

check for

updates

Citation: Kim, H.-K.; Kim, H.-R.; Yoon, S.-J.; Lee, K.-B.; Kim, J.; Kim, B.-C. Colorimetric Aptasensor for Detecting Bacillus carboniphilus Using Aptamer Isolated with a Non-SELEX-Based Method. Chemosensors 2021, 9, 121. https://doi.org/10.3390/ chemosensors 9060121

Academic Editor: Philip Gardiner

Received: 30 March 2021

Accepted: 20 May 2021

Published: 24 May 2021

Publisher's Note: MDPI stays neutral with regard to jurisdictional claims in published maps and institutional affiliations.

Copyright: (c) 2021 by the authors. Licensee MDPI, Basel, Switzerland. This article is an open access article distributed under the terms and conditions of the Creative Commons Attribution (CC BY) license (https:/ / creativecommons.org/licenses/by/ $4.0 /)$.

\begin{abstract}
B. carboniphilus is a naphtha-degradative strain (NDS) that uses hydrocarbons for its growth and causes microbiologically influenced corrosion (MIC) in naphtha pipelines. To date, there have been no studies on receptors or sensors for the detection of B. carboniphilus. We isolate B. carboniphilus-specific aptamers with a non-SELEX-based method, which employs repetitive cycles of centrifugation-based partitioning. The binding affinities of three aptamers are evaluated by obtaining their dissociation constants $\left(\mathrm{K}_{\mathrm{d}}\right)$, which range from 13.2 to $26.3 \mathrm{nM}$. The BCA-05 aptamer with the lowest $K_{d}$ value is employed for a two-stage label-free aptasensing platform to verify the aptamer selectivity using colorimetric detection of B. carboniphilus. This platform starts with the aptamer-bacteria binding step, and the concentration of residual aptamer after binding depends on the amount of the target bacteria. Then, the amount of separated residual aptamer determines the degree of salt-induced aggregation of gold nanoparticles (AuNPs), which results in a color change from red to blue. The AuNP color change is expressed as the ratio of absorbances at 630 and $520 \mathrm{~nm}$ (A630/A520). Under optimized conditions, this aptasensor shows reliable performance with a linear correlation in the range $10^{4}-10^{7} \mathrm{CFU} \mathrm{mL}-1$ and a limit of detection of $5 \times 10^{3} \mathrm{CFU} \mathrm{mL}^{-1}$.
\end{abstract}

Keywords: Bacillus carboniphilus; gold nanoparticle; colorimetric aptasensor; bacteria-specific aptamer; non-SELEX-based method

\section{Introduction}

Bacillus carboniphilus is a bacterial strain that requires carbon materials such as graphite or activated charcoal for its growth. It was first isolated from the air [1], but can also be found in desert soil [2]. There have been no reports that B. carboniphilus is harmful to humans, but it has been isolated from flacherie-infected silkworms. The pathogenicity of $B$. carboniphilus in silkworms was established via an infectivity test using Koch's postulates [3]. Interestingly, along with Serratia marcescens, Bacillus pumilus, and Bacillus megaterium, B. carboniphilus is a naphtha-degradative strain (NDS), which can cause microbiologically influenced corrosion (MIC) [4]. NDSs utilize hydrocarbon compounds such as cyclopentane, nonyl alcohol, and ethyl benzene as nutrients for their growth in naphtha pipelines. Oxygen from the degraded hydrocarbon compounds combines with ferric or manganese ions to form ferric/manganese oxides on the surface of the pipes. The growth of bacteria enhances and accelerates the corrosive process in the petroleum product pipelines [5]. It is estimated that MIC contributes to $40 \%$ of internal corrosion in the naphtha pipes, and $70-95 \%$ of internal leaks are due to localized corrosion caused by MIC [6]. Continuous corrosion can lead to oil spillage from pipelines, which causes environmental pollution and economic damage, and therefore, the proper monitoring of NDSs is required for the detection of 
the microorganisms involved in MIC of naphtha pipelines. Although there is a report about B. carboniphilus [4], this bacterium did not receive much attention. In the case of this bacterium, its genetic information or receptors for diagnostic analysis are rarely known. However, sometimes the diagnosis of microorganisms that are less of a concern is suddenly necessary. If we can prepare reliable target-specific receptors for them rapidly, it is possible to set up diagnostic systems in an emergency situation. From this point of view, we chose B. carboniphilus for which not many studies have been reported.

There are various types of bioreceptors and sensing platforms for whole-cell bacterial detection $[7,8]$. For example, Altintas et al. immobilized a polyclonal rabbit anti-Escherichia coli antibody on a gold sensor chip surface as part of a fully automated microfluidic-based electrochemical sensor [9]. Antimicrobial peptides (AMPs) of the immune system are short peptides with polycationic or amphiphilic characteristics that recognize and interact with bacteria via physicochemical interactions [10]. They have mainly been studied for therapeutic uses or antibacterial applications, such as antifouling [11-13]. Recently, AMPs have been used as ligands in biosensors to detect whole-cell bacteria because of their broad-spectrum specificity $[14,15]$. A microarray chip coupled with multiple AMPs was designed for surface plasmon resonance imaging (SPRI) by Pardoux et al., in which pathogens can be detected using this multiplexing AMP array within $20 \mathrm{~h} \mathrm{[16].} \mathrm{Kim} \mathrm{et} \mathrm{al.} \mathrm{reported} \mathrm{a} \mathrm{two-stage} \mathrm{label-free} \mathrm{aptasensing} \mathrm{platform} \mathrm{for} \mathrm{the}$ detection of Cronobacter sakazakii in powdered infant formula [17]. Aptamers are synthetic oligonucleotides that have affinity and specificity to target molecules such as chemicals, proteins, or cells [18]. This aptasensing platform utilizes gold nanoparticles (AuNPs), salts, and residues from label-free aptamers bound with C. sakazakii. The color change of AuNPs indicates the concentration of target bacteria because salt induces the aggregation of AuNPs via salting-out mechanism, while aptamers interfere with salt-induced AuNP aggregation [19]. However, there are still no reports on probes (aptamers or antibodies) or sensors for the detection of $B$. carboniphilus.

As one of the sensor probes, aptamers have advantages over antibodies. It takes about 2-8 weeks to select the target-specific aptamer, while the discovery of an antibody usually takes time more than 6 months [20]. In addition, aptamers are generally stable for changes in temperature and $\mathrm{pH}$, and can be stored in any buffer at room temperature, while protein probes such as antibodies and AMPs are sensitive to temperature and $\mathrm{pH}$ [21]. Aptamers are usually selected from a random DNA library (RDL) using the systematic evolution of ligands by exponential enrichment (SELEX) [22]. Oligonucleotides, which bind to the target, undergo repetitive exponential enrichment processes, consisting of binding, partitioning, and amplification. In the case of bacteria-specific aptamers, Cell-SELEX is commonly used for the selection of aptamers that bind specifically surface molecules on the surface of the target bacteria [23,24]. Cell-SELEX has the advantage that it can be performed without prior knowledge of target cell surface proteins or purified target molecules [25]. However, the process still includes repetitive enrichment steps of over 10-30 cycles, making this method time-intensive, and it requires a large amount of the target cells for every cycle $[24,26]$. We recently proposed a rapid method for the isolation of bacterial cell-specific aptamers [27], where unbound single-stranded DNA can be eliminated from the pool via a repetitive centrifugation-based partitioning method. The aptamers, isolated via this centrifugation-based partitioning method, showed comparable performance to those isolated by SELEX.

In this study, we quickly screened the aptamer receptors for B. carboniphilus, which has not received much attention, and showed that it can be selectively detected by applying aptamers to sensor platforms. B. carboniphilus-specific aptamers were isolated using a centrifugation-based partitioning method. One of the isolated aptamers with the highest binding affinity was then employed for a two-stage label-free aptasensing platform by using AuNPs [17] for the rapid detection of B. carboniphilus. We investigated optimizing conditions for the concentration of $\mathrm{NaCl}$ and aptamers that induce colorimetric signals. The limit of detection (LOD) of colorimetric aptasensor was examined. The enrichment 
process was also devised for the detection of target bacteria at lower concentrations than the detection limit. The specificity of the colorimetric aptasensor was verified with non-target bacteria and various types of microbeads. Through this study, we believe that it is possible to screen receptors rapidly for various microorganisms that have not yet been noticed and to develop diagnostic sensors rapidly.

\section{Materials and Methods}

\subsection{Bacterial Strains and Culture}

Bacillus carboniphilus (KCTC 3837), Bacillus cereus (KCTC 3711), Bacillus pumilus (KCTC 3714), Bacillus megaterium (KCTC 3712), Bacillus subtilis (KCTC 1022), Escherichia coli (KCTC 2571), Escherichia hermannii (KCTC 22526), Shigella sonnei (KCTC 2518), Shigella flexneri (KCTC 2993), Staphylococcus aureus (KCTC 1621), Staphylococcus haemolyticus (KCTC 3341), Staphylococcus xylosus (KCTC 3342), Staphylococcus auricularis (KCTC 3584), Listeria grayi (KCTC 3443), Klebsiella aerogenes (KCTC 2190), Klebsiella pneumonia (KCTC 2208) Enterobacter cloacae (KCTC 1685), Citrobacter braakii (KCTC 2006), and Micrococcus luteus (KCTC 9857) were purchased from the Korean Collection for Type Culture (Daejeon, Korea). Nutrient broth and nutrient agar were purchased from Becton Dickinson and Company (Franklin Lakes, NJ, USA). B. subtilis, B. cereus, E. coli, E. hermannii, S. sonnei, S. aureus, L. grayi, S. flexneri, K. aerogenes, E. cloacae, and C. braakii were cultivated at $37^{\circ} \mathrm{C}$ in nutrient broth. S. haemolyticus and S. xylosus were cultivated at $37^{\circ} \mathrm{C}$ in nutrient broth containing $0.5 \% \mathrm{NaCl}$. S. auricularis was cultivated at $37{ }^{\circ} \mathrm{C}$ in Corynebacterium broth. M. luteus, B. pumilus, and B. megaterium were cultivated at $30^{\circ} \mathrm{C}$ in nutrient broth. B. carboniphilus was cultivated at $30{ }^{\circ} \mathrm{C}$ in nutrient broth containing $0.5 \% \mathrm{NaCl}$. S. xylosus and B. carboniphilus were cultivated without $\mathrm{NaCl}$ when used in the colorimetric aptasensor test.

\subsection{Isolation of Bacillus carboniphilus-Specific Aptamers Using a Centrifugation-Based Partitioning Method}

Both target and negative cell species were cultured to $10^{7} \mathrm{CFU} \mathrm{mL} \mathrm{m}^{-1}$, respectively. From each cell solution, an aliquot of $5 \mathrm{~mL}$ was collected and centrifuged at 13,000 rpm for $5 \mathrm{~min}$. The culture medium was decanted, and the cell pellets were washed three times with washing buffer $(1 \times$ Phosphate-buffered saline, PBS containing $137 \mathrm{mM} \mathrm{NaCl}, 2.7 \mathrm{mM} \mathrm{KCl}$, $10 \mathrm{mM} \mathrm{Na}_{2} \mathrm{HPO}_{4}$, and $1.8 \mathrm{mM} \mathrm{KH}_{2} \mathrm{PO}_{4}$ ). Positive cell pellets were suspended in $400 \mu \mathrm{L}$ binding buffer $\left(1 \times\right.$ PBS, $0.45 \%$ glucose, $50 \mathrm{mM} \mathrm{MgCl}_{2}, 0.1 \%$ bovine serum albumin, $0.01 \%$ tRNA). All negative cell pellets were suspended and combined with $400 \mu \mathrm{L}$ of binding buffer. A random ssDNA library $(400 \mu \mathrm{L} 500 \mathrm{nM} 88$ mer, 5'-GCA ATG GTA CGG TAC TTC C-N 45 -CAA AAG TGC ACG CTA CTT TGC TAA-3'; Genotech, Daejeon, Korea) was added to the negative cell solution after denaturation at $95{ }^{\circ} \mathrm{C}$ for $5 \mathrm{~min}$, followed by fast cooling on ice. The mixture was incubated at $25^{\circ} \mathrm{C}$ for $1 \mathrm{~h}$ in a rotator (Multi Bio RS-24, Biosan, Riga, Latvia) at $100 \mathrm{rpm}$. Unbound ssDNA was separated using an Ultrafree ${ }^{\circledR}-\mathrm{MC}$ PVDF $0.1 \mu \mathrm{m}$ centrifugal filter (Merck Millipore, Darmstadt, Germany) at 13,000 rpm for $3 \mathrm{~min}$. The flow-through solution was added to the target cell solution and mixed at $25^{\circ} \mathrm{C}$ for $1 \mathrm{~h}$ in a rotator at $100 \mathrm{rpm}$. The mixture in the filter device was centrifuged at $13,000 \mathrm{rpm}$ for $3 \mathrm{~min}$. The washing step was performed by gently pipetting the cell pellet in a filter membrane with $500 \mu \mathrm{L}$ washing buffer with centrifugation at 13,000 rpm for $3 \mathrm{~min}$ and repeated 10 times. In the last washing step, cell pellets with bound ssDNA were suspended in $500 \mu \mathrm{L}$ elution buffer $(1 \times \mathrm{PBS}, 0.45 \%$ glucose, $50 \mathrm{mM} \mathrm{MgCl}, 0.1 \%$ bovine serum albumin) and transferred into $1.5 \mathrm{~mL}$ microtubes. The cell mixture was heated at $95^{\circ} \mathrm{C}$ for $5 \mathrm{~min}$, followed by centrifugation using a filter device at 13,000 rpm for $3 \mathrm{~min}$. The flow-through solution was moved to a $1.5 \mathrm{~mL}$ microtube. Target-bound ssDNA solution was added to the negative cell solution, mixed thoroughly, and incubated at $25^{\circ} \mathrm{C}$ for $1 \mathrm{~h}$ in a shaking incubator at $100 \mathrm{rpm}$. The mixture was centrifuged using a filter device at 13,000 rpm for $3 \mathrm{~min}$. The flow-through solution containing target-bound ssDNA was transferred into a $1.5 \mathrm{~mL}$ microtube. 
PCR was performed to amplify the target-bound ssDNA with primers (Genotech, forward primer: 5'-GCA ATG GTA CGG TAC TTC C-3', reverse primer: 5'-TTA GCA AAG TAG CGT GCA CTT TTG-3'). Conditions of the PCR reaction started from the hot start step at $95^{\circ} \mathrm{C}$ for $150 \mathrm{~s}$. The template was incubated at $95^{\circ} \mathrm{C}$ for $30 \mathrm{~s}$ during the denaturation step. Annealing was performed at $56.3{ }^{\circ} \mathrm{C}$ for $30 \mathrm{~s}$, followed by extension at $72{ }^{\circ} \mathrm{C}$ for $30 \mathrm{~s}$. The steps from denaturation to extension were repeated for 10 cycles, and the final extension was performed at $72{ }^{\circ} \mathrm{C}$ for $3 \mathrm{~min}$. In the second PCR conditions, the steps from denaturation to extension were repeated for 8 cycles, and the other conditions were the same as the first PCR. The PCR products were identified by agarose gel electrophoresis on a $3 \%$ agarose gel at $100 \mathrm{~V}$ for $60 \mathrm{~min}$.

The pCR $^{\mathrm{TM}}$ 2.1-TOPO ${ }^{\circledR}$ TA vector (Invitrogen, Carlsbad, CA, USA) was used for cloning. Vector with dsDNA was transformed into E. coli DH5 $\alpha$ competent cells (Takara Bio, Shiga, Japan). After the blue-white screening, white colonies were cultured in LuriaBertani broth containing $50 \mu \mathrm{g} \mathrm{mL}-1$ ampicillin. Plasmid preparation was performed using the PureLink ${ }^{\circledR}$ Quick Plasmid Miniprep Kit (Invitrogen, Carlsbad, CA, USA). The DNA sequences were determined by sequence analysis (Macrogen Inc., Seoul, Korea). Three ssDNA aptamer sequences were selected after predicting the 3-dimensional structure of ssDNA with Mfold [28].

\subsection{Affinity Test and Specificity Test}

B. carboniphilus was cultured at $10^{7} \mathrm{CFU} \mathrm{mL} \mathrm{m}^{-1}\left(\mathrm{OD}_{600} \mathrm{~mL}^{-1}=7.6 \times 10^{7} \mathrm{CFU} \mathrm{mL}^{-1}\right)$. One milliliter of cell solution was centrifuged at 13,000 rpm for $3 \mathrm{~min}$, and the cell pellet was washed three times with $1 \times$ PBS. The cells were diluted to a concentration of $10^{6} \mathrm{CFU} \mathrm{mL}{ }^{-1}$ with $1 \mathrm{~mL} 1 \times$ PBS. A $100-\mu \mathrm{L}$ aliquot of diluted target cell solution was mixed with $100 \mu \mathrm{L}$ each FAM-modified aptamer at concentrations of 10, 25, 50, 100, 250, and $500 \mathrm{nM}$. The mixed solutions were incubated in a shaking incubator at $250 \mathrm{rpm}$ for $1 \mathrm{~h}$. The mixtures were moved to a centrifugal filter device and centrifuged at 13,000 rpm for $3 \mathrm{~min}$. One hundred microliters of $1 \times$ PBS buffer were added to the filter unit and suspended in a thermomixer (Eppendorf, Hamburg, Germany) at $1200 \mathrm{rpm}$ for $10 \mathrm{~min}$. The relative fluorescence unit value was measured three times at $521 \mathrm{~nm}$ using a NanoDrop 3300 (Thermo Fisher Scientific, Wilmington, DE, USA).

B. carboniphilus, E. coli, S. xylosus, B. cereus, B. subtilis, and M. luteus were cultured to $10^{7} \mathrm{CFU} \mathrm{mL}{ }^{-1}$. Each cell solution $(1 \mathrm{~mL})$ was centrifuged at 13,000 rpm for $3 \mathrm{~min}$, and the cell pellet was washed three times in $1 \times$ PBS. Each cell was suspended in $1 \mathrm{~mL} 1 \times$ PBS. The FAM-aptamer (500 $\mu \mathrm{L} 500 \mathrm{nM}$ BCA-05) was mixed with $500 \mu \mathrm{L}$ of the target cell or negative cell solutions. The mixed solutions were incubated in a shaking incubator at $250 \mathrm{rpm}$ for $30 \mathrm{~min}$. The mixtures were then moved to a centrifugal filter device and centrifuged at 13,000 rpm for $3 \mathrm{~min}$. One hundred microliters $1 \times$ PBS buffer was added to the filter unit and suspended in a thermomixer at $1200 \mathrm{rpm}$ for $10 \mathrm{~min}$. The relative fluorescence unit value was measured at $521 \mathrm{~nm}$ three times using a NanoDrop 3300.

\subsection{Colorimetric Aptasensor Detection of B. carboniphilus}

AuNPs were synthesized by simple reduction of $\mathrm{HAuCl}_{4}$ with trisodium citrate (Sigma Aldrich) [28]. $40 \mathrm{mg} \mathrm{HAuCl}_{4}$ was dissolved in water $(100 \mathrm{~mL})$. The solution was heated at $95^{\circ} \mathrm{C}$ with continuous stirring in a reflux condenser, and $10 \mathrm{mM}$ trisodium citrate was injected into the solution upon boiling, after which the solution was heated under reflux for $30 \mathrm{~min}$. The solution was cooled to room temperature and stored in a refrigerator at $4{ }^{\circ} \mathrm{C}$.

B. carboniphilus was cultured at $10^{7} \mathrm{CFU} \mathrm{mL}{ }^{-1}$. The cell solution $(2 \mathrm{~mL})$ was centrifuged at 13,000 rpm for $5 \mathrm{~min}$, and the cell pellet was washed three times in $2 \mathrm{~mL} 10 \mathrm{mM}$ phosphate buffer ( $\mathrm{PB}, \mathrm{pH}$ ). Then, $10^{7} \mathrm{CFU} \mathrm{mL} \mathrm{mL}^{-1}$ B. carboniphilus solution was serially diluted 10-fold down to $10^{1} \mathrm{CFU} \mathrm{mL}{ }^{-1}$. One milliliter of each cell solution with various concentrations was centrifuged at $13,000 \mathrm{rpm}$ for $10 \mathrm{~min}$, and $910 \mu \mathrm{L}$ of the supernatant was removed by gentle pipetting. Then, $10 \mu \mathrm{L} 2.5 \mu \mathrm{M}$ BCA- 05 aptamer was added to $90 \mu \mathrm{L}$ target cell solution at varying concentrations, followed by mixing with a thermomixer at 
$1200 \mathrm{rpm}$ for $30 \mathrm{~min}$. The mixture was moved to a centrifugal filter device and centrifuged at 13,000 rpm for $2 \mathrm{~min}$. One hundred microliters flow-through solution was added to $20 \mu \mathrm{L}$ $20 \mathrm{~nm}$ gold nanoparticles (AuNPs) and mixed by pipetting several times. Then, $10 \mu \mathrm{L} 0.6 \mathrm{M}$ $\mathrm{NaCl}$ was added to the AuNP/aptamer mixture. The absorbance value was measured three times at 520 and $630 \mathrm{~nm}$ using an ultraviolet-visible absorption spectrometer (Nanodrop One C, Thermo Scientific, Wilmington, DE, USA).

For the enrichment process, each cell solution $(10 \mathrm{~mL})$ of $10^{2}$ and $10^{3} \mathrm{CFU} \mathrm{mL} \mathrm{mL}^{-1}$ B. carboniphilus in $50 \mathrm{~mL}$ conical tube was centrifuged at $4000 \mathrm{rpm}$ for $30 \mathrm{~min}$. Each $9 \mathrm{~mL}$ of the supernatants was removed, and residual cell solution $(1 \mathrm{~mL})$ was transferred into a $1.5 \mathrm{~mL}$ microtube. The concentrated cell solutions were used for the colorimetric aptasensor for detecting B. carboniphilus.

\subsection{Detection of the Target in Bacterial Mixture and Biofilm}

For the detection of B. carboniphilus in bacterial mixture, B. carboniphilus, B. subtilis,

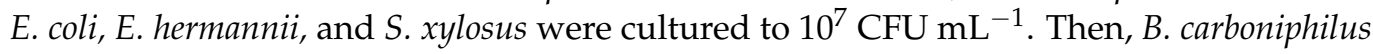
cells were spiked into the non-target bacterial mixture (B. subtilis, E. coli, E. hermannii, and $S$. $x$ ylosus) so that the samples contained non-target bacteria at the same concentration of $10^{5} \mathrm{CFU} \mathrm{mL} \mathrm{mL}^{-1}$ for each strain (B. subtilis, E. coli, E. hermannii, and S. xylosus) and the target cells with various concentrations from $10^{3}$ to $10^{7} \mathrm{CFU} \mathrm{mL}{ }^{-1}$. For the preparation of biofilm samples, we prepared three different types of them (non-target bacterial mixture, target, and target in bacterial mixture). Each $1 \mathrm{~mL}$ of the non-target bacterial mixture (mixture of each $10^{5} \mathrm{CFU} \mathrm{mL}{ }^{-1}$ B. subtilis, E. coli, E. hermannii, and S. xylosus), target $\left(10^{7} \mathrm{CFU} \mathrm{mL}^{-1}\right)$, or target in bacterial mixture $\left(10^{7} \mathrm{CFU} \mathrm{mL}^{-1}\right.$ of $B$. carboniphilus, and mixture of each $10^{5}$ CFU mL $\mathrm{mL}^{-1}$ B. subtilis, E. coli, E. hermannii, and S. xylosus) was spread on a nutrient agar plate and incubated at $30{ }^{\circ} \mathrm{C}$ for two days [29,30]. After forming biofilms, we sampled biofilms by scrapping three different positions $(1 \mathrm{~cm}$ by $1 \mathrm{~cm})$ on one plate using sterilized micropipette tips. The scrapped biofilms were washed three times, suspended, and then diluted 10 times using PB. The prepared mixture or biofilm samples were used for the colorimetric aptasensor test, as mentioned previously.

\section{Results and Discussion}

\subsection{Selection and Characterization of Bacillus carboniphilus-Specific Aptamer}

B. carboniphilus-specific aptamers were isolated from a random ssDNA library using the centrifugation-based partitioning method (CBPM) (Figure 1). The negative selection was performed twice by eliminating the ssDNA bound with non-target bacteria. The positive selection was also performed between the negative selection steps to ensure the specificity of aptamers for the target bacteria. Unlike the conventional SELEX-based method, this CBPM method does not require exponential enrichment steps such as binding, elution, amplification, and separation. Instead, unbound or weakly bound oligonucleotides can be eliminated from the pool by repetitive centrifugation-partitioning during the washing step. We reported this simplified method in isolating E. coli-specific aptamers [27]. The aptamers isolated via the CBPM had comparable dissociation constant $\left(\mathrm{K}_{\mathrm{d}}\right)$ values with those of the aptamers isolated by SELEX, and showed high specificity. We demonstrated that aptamers with good performance could be obtained via this CBPM method in less time than SELEX. Therefore, based on our previous study, the CBPM method can be replaced with conventional SELEX for the isolation of B. carboniphilus-target aptamers.

A total of 10 cycles of CBPM partitioning were performed in order to obtain oligonucleotides, which could be amplified by PCR. PCR was performed twice, followed by gel electrophoresis for identifying the size of amplified DNA in the product. A clear 88 bp PCR product (the size of the random single-stranded DNA) was observed clearly in agarose gel electrophoresis analysis (Figure S1). Total 25 different sequences were obtained (Table S1), and all sequences were predicted by Mfold to have stem-loop structures, which are crucial in checking the binding affinities of aptamers [31,32]. Three candidates (BCA-05, BCA-14, 
and BCA-23) were chosen depending on the number of stem-loop structures (Table 1,

Figure S2) and evaluated for their binding affinities to target bacteria.

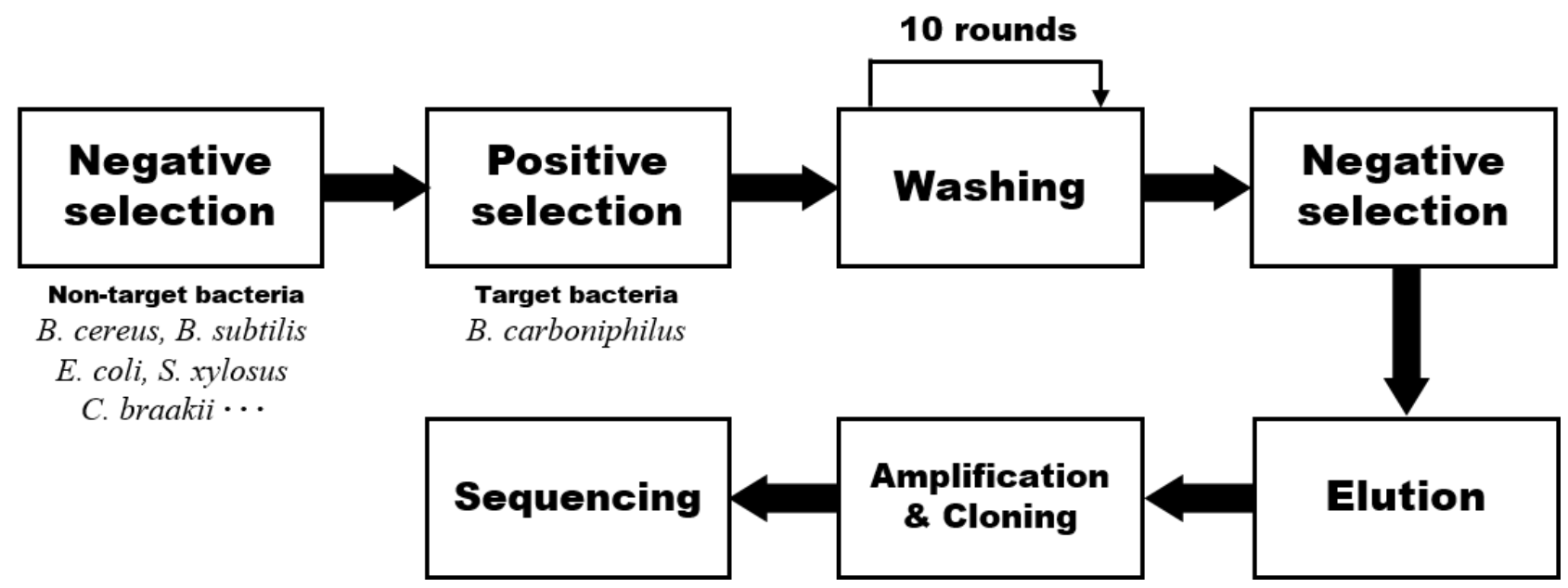

Figure 1. Schematic representation of the centrifugation-based partitioning method for the isolation of B. carboniphilusspecific aptamers. In negative selection, the unbound oligonucleotides were filtered after a random DNA library was mixed with non-target bacteria. In positive selection, oligonucleotides bound with target bacteria, followed by separating them from unbound oligonucleotides. This separating process was repeated several rounds in the washing step by centrifugal filtration and suspension. In this study, the washing step was repeated 10 times.

Table 1. Sequences of B. carboniphilus-specific aptamers, isolated using a centrifugation-based partitioning method.

\begin{tabular}{cc}
\hline Aptamer & Sequences of Random Region \\
\hline BCA-05 & CGG ACG GCT CTC GGG TTC TGC GGG TGT AAC CGA GAA ATA TCT ACG \\
BCA-14 & TGA TTT GGT TCC ACT GTT GCG GAG GGG TCT TAC TGC TAG TGG TTT \\
BCA-23 & TTG TCG CAT CAA TTT TTT TTT CAT CTG GTA GGC TCG CGA TTT C \\
\hline
\end{tabular}

The 3'-FAM dye-labeled sequences were incubated with B. carboniphilus and washed to produce binding saturation curves by fluorescence analysis (Figure $2 \mathrm{a}-\mathrm{c}$ ). The dissociation constants $\left(\mathrm{K}_{\mathrm{d}}\right)$ of BCA-05, BCA-14, and BCA-23 were estimated to be 13.2, 26.3, and $18.2 \mathrm{nM}$, respectively. BCA-05 with the lowest dissociation constant was used for the follow-up selectivity test by using non-target bacteria (E. coli, S. xylosus, B. cereus, B. subtilis, and $M$. luteus) as well as $B$. carboniphilus. The fluorescence intensity of $3^{\prime}$-FAM-labeled BCA-05 for non-target bacteria was much lower than that for target bacteria, which was less than $20 \%$ of the maximum intensity of the target bacteria. This result suggests that the BCA-05 sequence had good affinity and selectivity for the target; therefore, we employed this sequence for the two-stage label-free aptasensing platform for the detection of B. carboniphilus.

\subsection{Optimization of a Colorimetric Aptasensor for Detecting B. carboniphilus}

The schematic illustration in Figure 3 describes the system of the two-stage label-free colorimetric aptasensor [17]. In the presence of target bacteria, the concentration of residual aptamers is lower than that in the absence of target bacteria. When the fewer population of free aptamers in the presence of higher target cell concentration would be adsorbed on gold nanoparticles, more gold nanoparticles aggregate and shift the indicator color from red to blue in a more rigorous way (Figure 3a). On the other hand, more aptamers with lower target cells would make the gold nanoparticles more electrically stable from salt-induced aggregation so that they maintain their red color (Figure $3 b$ ). This color change can be reflected by calculating the ratio of absorbances at $630 \mathrm{~nm}$ and $520 \mathrm{~nm}$ (A630/A520). We separated the unbound aptamers from the target bacteria/aptamer complexes simply 
using a centrifugal filter, not direct centrifugation (Figure 3c). In direct centrifugation, not only unbound aptamers but also bacterial cells can be transferred to AuNPs solution. Citrate-capped AuNPs are likely to adhere to the surfaces of bacterial cells [33], which can inhibit the interaction between AuNPs and aptamers. On the other hand, the centrifugal filter can efficiently remove invisible cells from the solution at low concentrations of target bacteria preventing AuNPs from adhesion to the bacterial cell surface. Then, the unbound aptamers in the flow-through solution can be adsorbed onto gold nanoparticles by simple mixing to address sensing results.

(a)
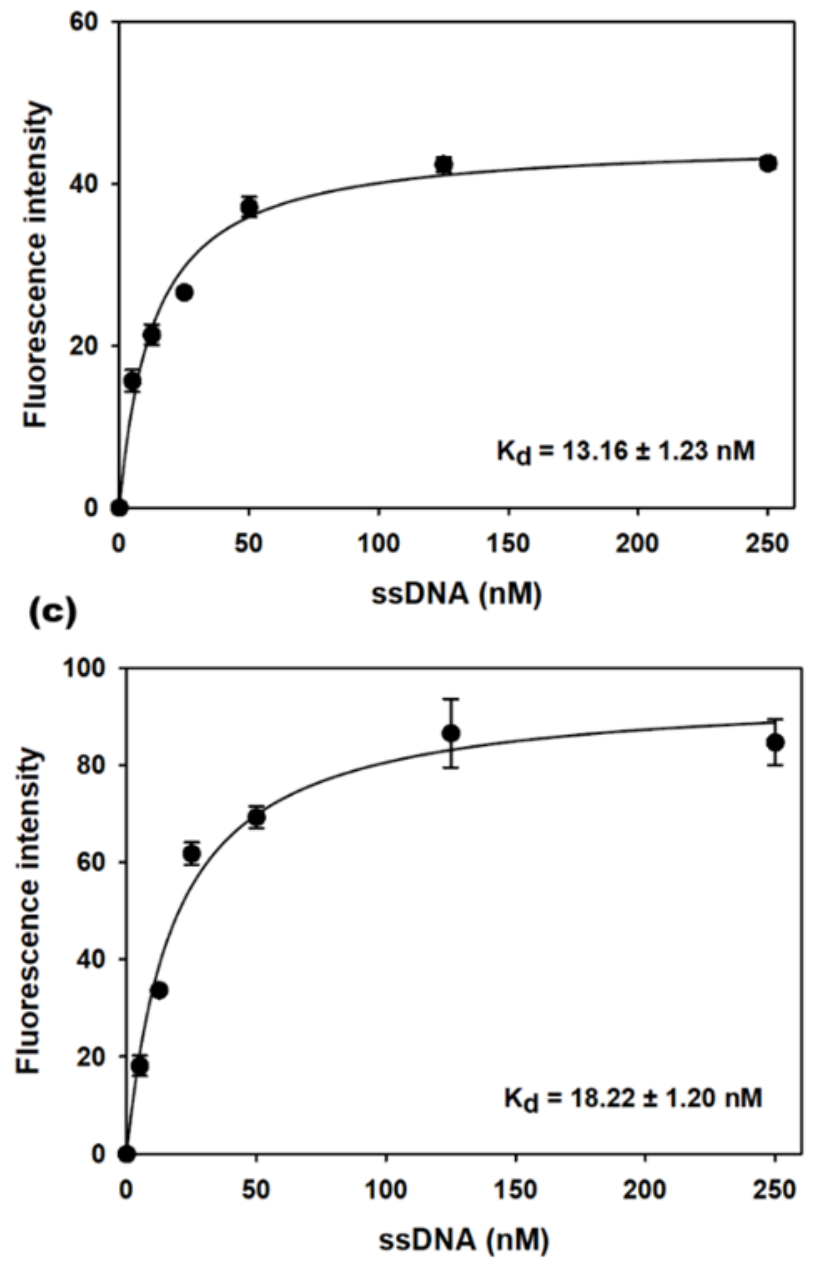

(b)

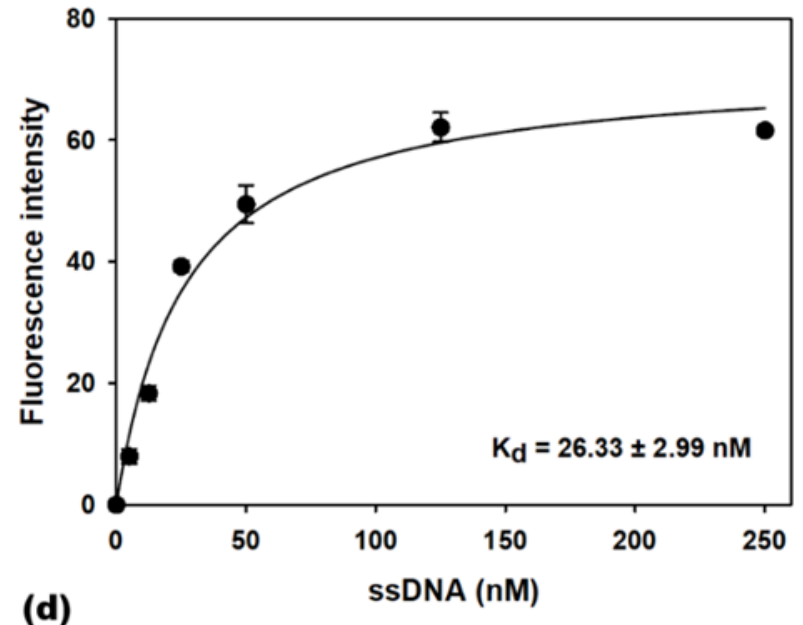

(d)

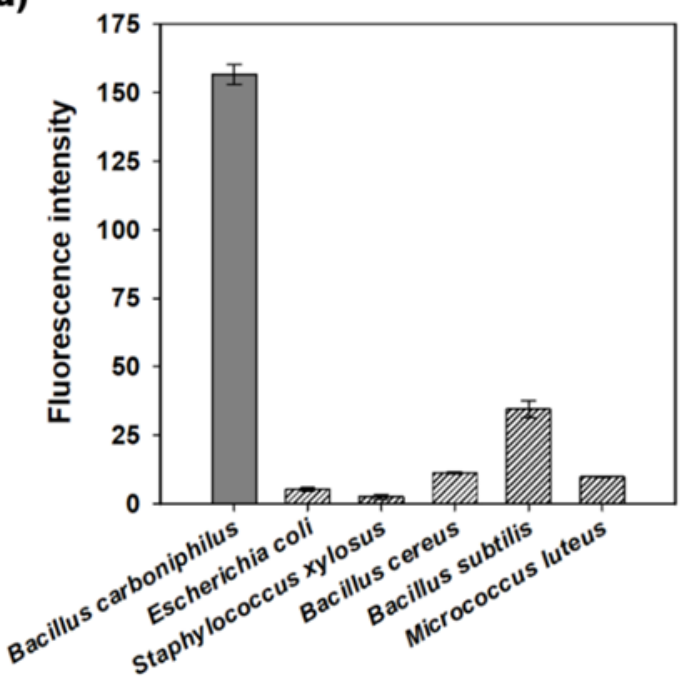

Figure 2. Saturation binding assay curves of the (a) BCA-05, (b) BCA-14, and (c) BCA-23 aptamers to target bacteria (B. carboniphilus). (d) the specificity of BCA-05 to non-target bacteria (E. coli, S. xylosus, B. cereus, B. subtilis, and M. luteus) at the concentration of $10^{7} \mathrm{CFU} \mathrm{mL}{ }^{-1}$. Dots and bars represent means, and error bars denote standard deviations of three measurements.

Sodium chloride is a strong electrolyte that can neutralize the repulsive force between citrate-capped gold nanoparticles [34,35]. The concentration of $\mathrm{NaCl}$ is one of the key parameters that determine the sensitivity of the colorimetric aptasensor. We tested a range of $\mathrm{NaCl}$ concentrations $(0-1.0 \mathrm{M})$ that were added to $20 \mu \mathrm{L}$ AuNP and $100 \mu \mathrm{L}$ PB in the absence of protection by the aptamers. Figure 4a shows that the A630/A520 values increased as the $\mathrm{NaCl}$ concentration was increased, with a value of more than 1.0 after $0.6 \mathrm{M} \mathrm{NaCl}$ was added to the solution. The color of AuNPs changed to clear blue when the $\mathrm{NaCl}$ concentrations equal to or above $0.6 \mathrm{M} \mathrm{NaCl}$ were added, while the AuNPs were still 
red or slightly purple at concentrations equal to or below $0.4 \mathrm{M} \mathrm{NaCl}$. Thus, $0.6 \mathrm{M} \mathrm{NaCl}$ was used for the follow-up experiments.

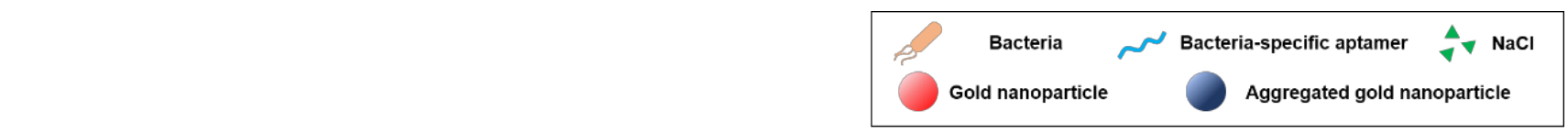

(a)

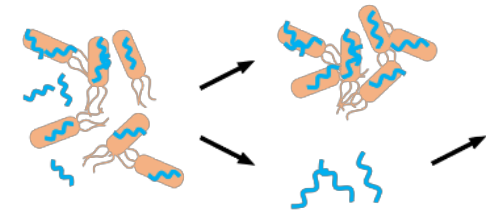

(b)
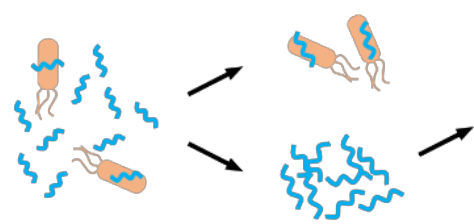
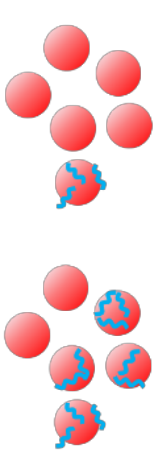
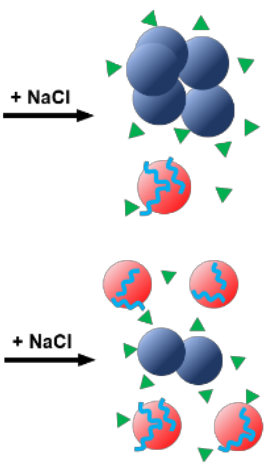

(c)

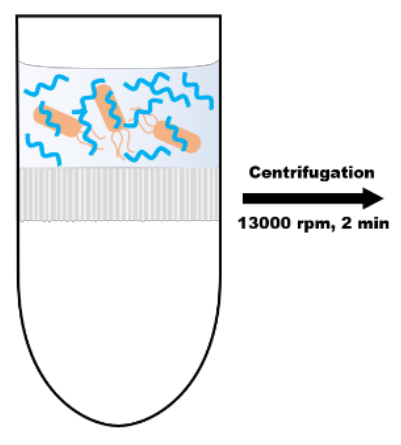

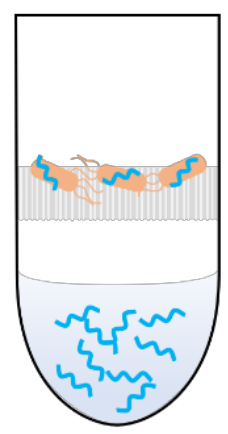

Figure 3. Schematic illustration of the two-stage label-free colorimetric aptasensor. (a) when most of the aptamer binds with target bacteria, a small number of unbound aptamers remains and is not able to protect the gold nanoparticles from salt aggregation, which shifts the color of the gold nanoparticles from red to blue. (b) if the aptamers do not specifically bind the target bacteria, there are enough unbound aptamers to protect gold nanoparticles, which maintain their red color. (c) the unbound aptamers can be separated from target/aptamer complexes using the centrifugal filter. All flow-through solution with the unbound aptamers was transferred to the AuNPs solution and mixed by pipetting simply.

(a)
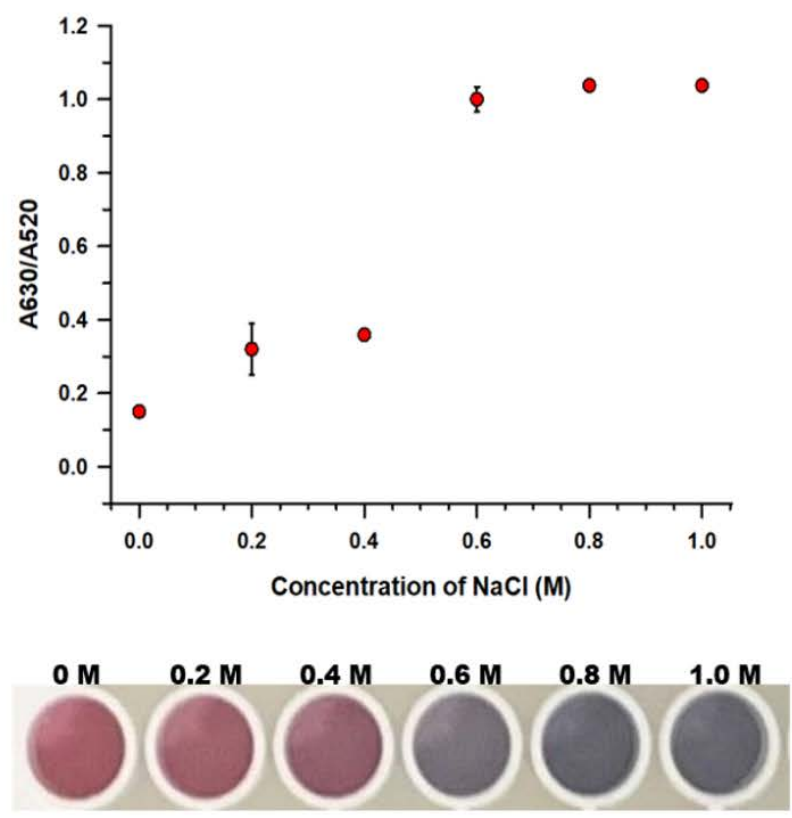

(b)
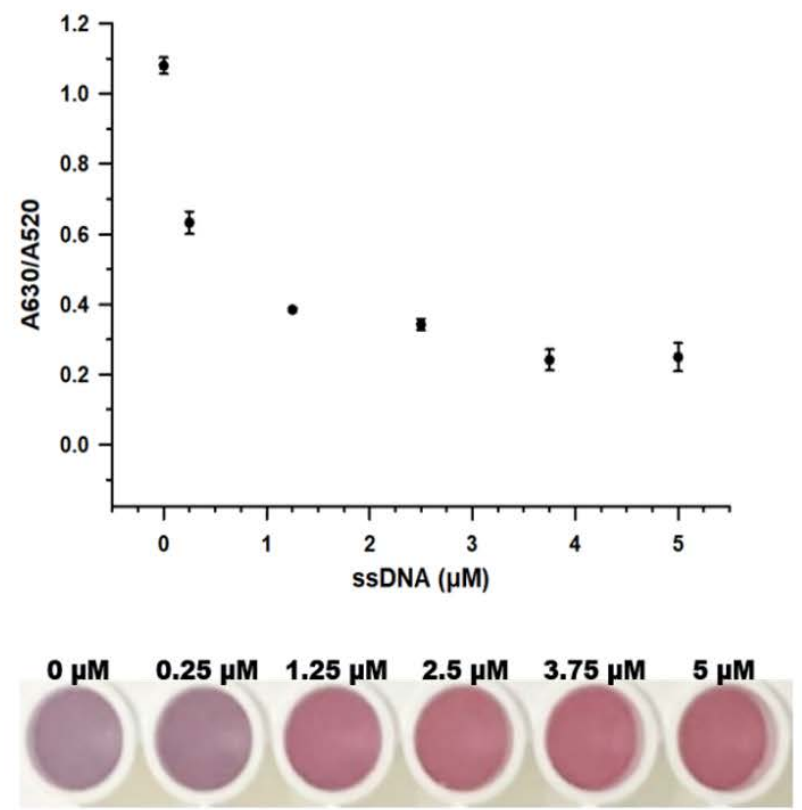

Figure 4. Optimizing the concentration of the key parameters. (a) $\mathrm{NaCl}$ and (b) the BCA-05 aptamer. The photographs below each graph illustrate the color change of AuNPs at each concentration of $\mathrm{NaCl}$ and the BCA-05 aptamer, respectively. The dots and error bars denote means and standard deviation, respectively, of three measurements.

To optimize the aptamer concentration, $10 \mu \mathrm{L}$ BCA-05 aptamer at various concentrations $(0,0.25,1.25,2.5,3.75$, and $5 \mu \mathrm{M})$ was mixed with $90 \mu \mathrm{L}$ PB and $20 \mu \mathrm{L}$ AuNPs. Then, $10 \mu \mathrm{L} 0.6 \mathrm{M} \mathrm{NaCl}$ was added, and the absorbance of the AuNPs was measured at 520 and $630 \mathrm{~nm}$. The AuNPs were more stable from salt-induced aggregation as more 
aptamers were added to the solution (Figure $4 \mathrm{~b}$ ). The AuNPs maintained their color above $1.25 \mu \mathrm{M}$ aptamer and showed low A630/A520 values at 3.75, $5 \mu \mathrm{M}$ of aptamer $(0.241$ and 0.248 , respectively). The A630/A520 value of $1.25 \mu \mathrm{M}$ was close to 0.4 (0.384), while that of $2.5 \mu \mathrm{M}$ was 0.342 . A higher aptamer concentration provided more stability to AuNPs from salt. However, this would increase the residual aptamer concentration, which can eventually reduce the detection sensitivity and cause the detection failures in the two-stage label-free aptasensing platform. Therefore, we selected $2.5 \mu \mathrm{M}$ BCA-05 aptamer as an optimal concentration for the aptasensor system.

As shown in Figure S3, the absorption spectrum of AuNPs with aptamer BCA-05 and $\mathrm{NaCl}$ (curve c, solid red line) was similar to that of bare AuNPs (curve a, solid black line). This indicates that oligonucleotides could protect the AuNPs from salt-induced aggregation. When $\mathrm{NaCl}$ was added to the bare AuNPs, there was no significant absorption peak at $520 \mathrm{~nm}$ in the spectrum (curve b) when compared to that of bare AuNPs (curve a). The same spectrum was obtained when AuNPs were mixed with the flow-through solution separated by the centrifugal filter after BCA- 05 binding with target B. carboniphilus (curve d) because the residual aptamers were insufficient to protect the AuNPs from salt-induced aggregation. Based on these spectral results, it can be concluded that the amount of residual aptamers affects the color changes and the A630/A520 values of the AuNPs. In addition, the presence of target cells in the sample solution could be detected by using this colorimetric aptasensor.

\subsection{The Performance of a Two-Stage Label-Free Aptasensor for Detecting B. carbonihpilus}

The performance of a colorimetric aptasensor for detecting B. carboniphilus was evaluated with different concentrations of the target bacteria (Figure 5a). The A630/A520 values were higher than those of the blank sample (0.311) and above $1 \times 10^{2} \mathrm{CFU} \mathrm{mL} \mathrm{m}^{-1}$ of the target $(0.327)$. The linear equation was $y=0.298 x-0.777$ with correlation $\left(R^{2}=0.988\right)$ ranging from $10^{4}-10^{7} \mathrm{CFU} \mathrm{mL} \mathrm{m}^{-1}$. The detection limit was $5 \times 10^{3} \mathrm{CFU} \mathrm{mL}^{-1}$, calculated as three standard deviations above the blank. The color of AuNPs gradually turned red to purple as the concentration of the target increased. The sample of $10^{4} \mathrm{CFU} \mathrm{mL-}{ }^{1}$ showed a slightly purple compared to the color of the blank sample, which demonstrated the concentration of the naked-eye detection limit. The aptasensor for C. sakazakii, which was first proposed for this platform, could detect as low as $7.1 \times 10^{3} \mathrm{CFU} \mathrm{mL}^{-1}$ [17]. The LODs of aptasensor for Campylobacter jejuni and Campylobacter coli were $7.2 \times 10^{5} \mathrm{CFU} \mathrm{mL} \mathrm{mL}^{-1}$ and $5.6 \times 10^{5} \mathrm{CFU} \mathrm{mL}{ }^{-1}$, respectively [36]. These results show that the performance of the aptasensor in this study is comparable to or slightly better than those of aptasensors on the same platform.

We also devised an enrichment process to detect the target at a concentration lower than the LOD. The enrichment process was to increase the final concentration of the sample by centrifugation and removal of the supernatant after obtaining ten times of volume with the same concentration as the original sample. Each $10 \mathrm{~mL}$ of the target cell solution with $10^{2}$ and $10^{3} \mathrm{CFU} \mathrm{mL}{ }^{-1}$ was concentrated to $10^{3}$ and $10^{4} \mathrm{CFU} \mathrm{mL}^{-1}$, respectively, by centrifugation for use in the colorimetric aptasensor process. As shown in Figure 5b, the A630/A520 values of the concentrated samples were compared to those of the original samples. The absorbance ratio values of the samples increased from 0.322

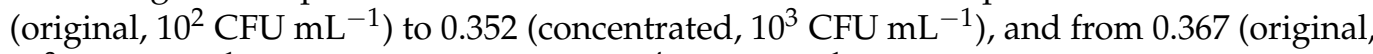
$10^{3} \mathrm{CFU} \mathrm{mL}^{-1}$ ) to 0.385 (concentrated, $10^{4} \mathrm{CFU} \mathrm{mL}^{-1}$ ). The increases in the A630/A520 values of the concentrated samples suggest that the enrichment process provides the possibility of detecting the target bacteria at a lower concentration than the LOD.

The specificity of the aptasensor was evaluated using $10^{7} \mathrm{CFU} \mathrm{mL}{ }^{-1}$ non-target bacteria. We also used various polystyrene microbeads with surface modifications (nonmodification, amine, carboxyl group, and bovine serum albumin) and magnetic microbeads with streptavidin to evaluate the target specificity at a concentration of $10^{7}$ beads $\mathrm{mL}^{-1}$. The A630/ A520 ratio associated with non-target bacteria and microbeads was lower than that of the target bacteria B. carboniphilus (Figure 5c). The color changes of non-target bacterial 
solutions were not significant, while that of target bacteria was deep blue, which indicated an acceptable performance of the colorimetric aptasensor. In addition, it was confirmed that the BCA-05 aptamer has low binding affinities to various types of microbeads, which affects the specificity of the aptasensor in this study.

(a)

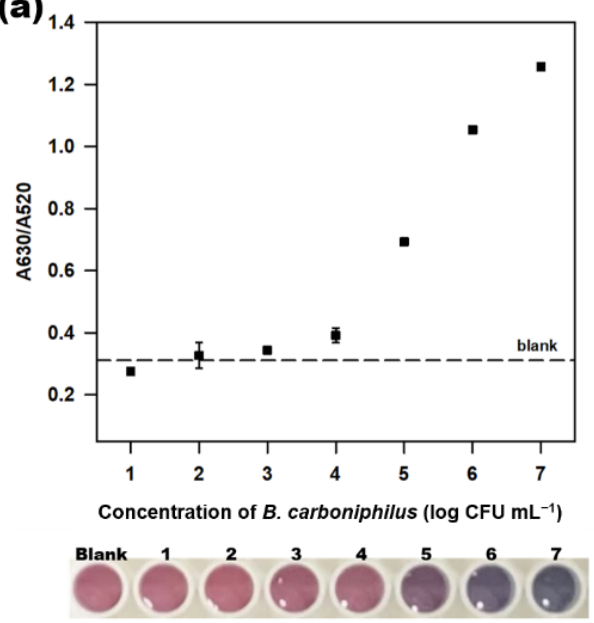

(b)

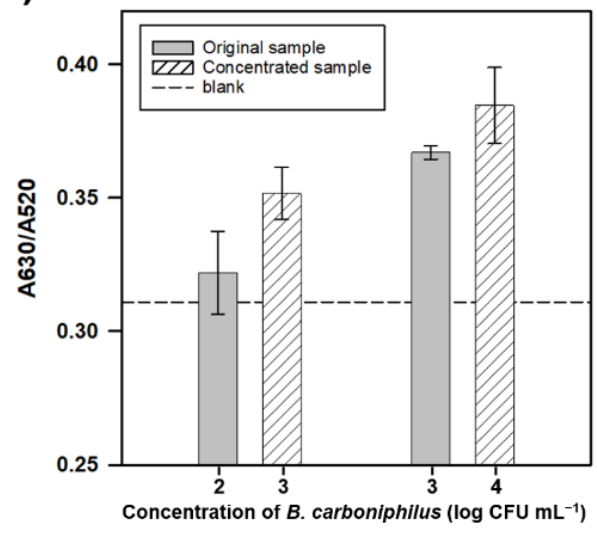

(c)

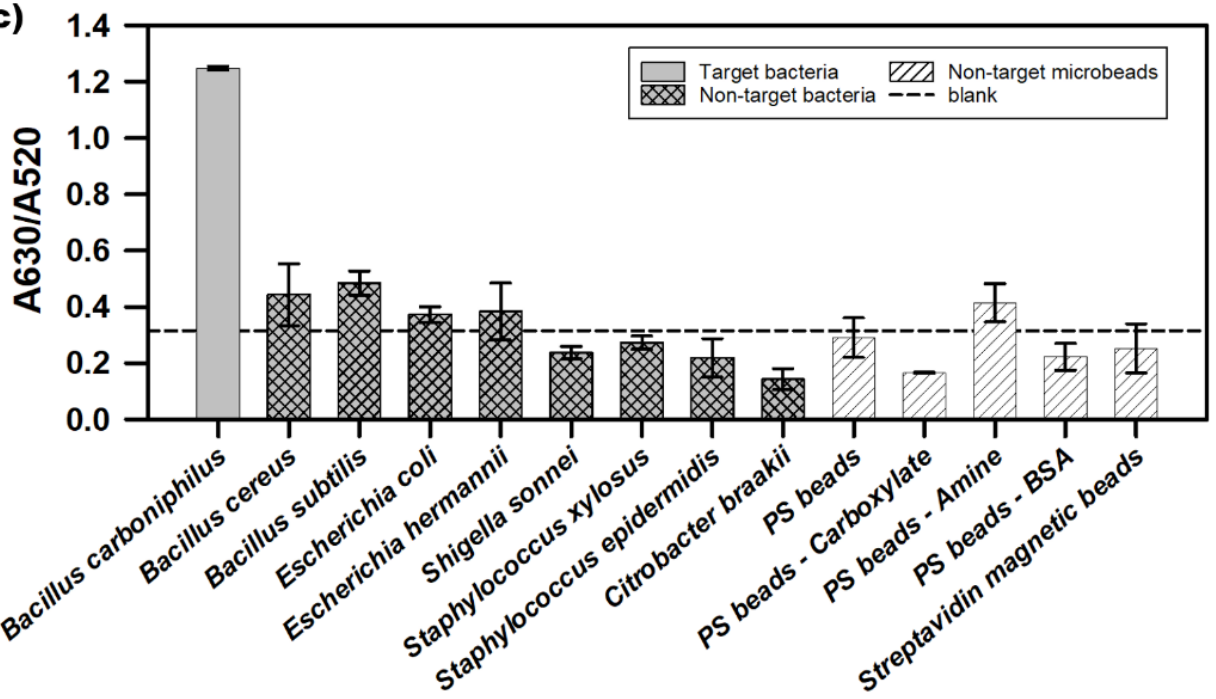

Figure 5. The performance of the colorimetric aptasensor for detecting Bacillus carboniphilus (KCTC 3837). (a) the linearity of the colorimetric aptasensor in detecting B. carboniphilus. The photograph below shows the color changes of the AuNPs at each concentration of the target bacteria; (b) comparison of the A630/A520 values of the standard B. carboniphilus samples with those of the concentrated sample; (c) specificity test of colorimetric aptasensor for detection of B. carboniphilus. Dots and bars represent means, and error bars denote standard deviations of three measurements.

\subsection{Specific Detection of B. carboniphilus in Bacterial Mixture and Biofilm}

Specific qualification of NDSs is important for diagnosing MIC because all microorganisms on the corrosion site are not directly related to the corrosive process. The selectivity test of the colorimetric aptasensor was performed by detecting the target, B. carboniphilus, in bacterial mixture. As shown in Figure 6a, the A630/A520 values of spiked samples increased as the concentration of the target cells increased linearly $\left(R^{2}=0.971\right)$. The color of AuNPs of the spiked sample $\left(10^{4} \mathrm{CFU} \mathrm{mL} \mathrm{m}^{-1}\right)$ showed a red-violet distinct from that of the blank. These results demonstrate that the colorimetric aptasensor can detect targets with well-selected aptamers in bacterial mixture. 
(a)

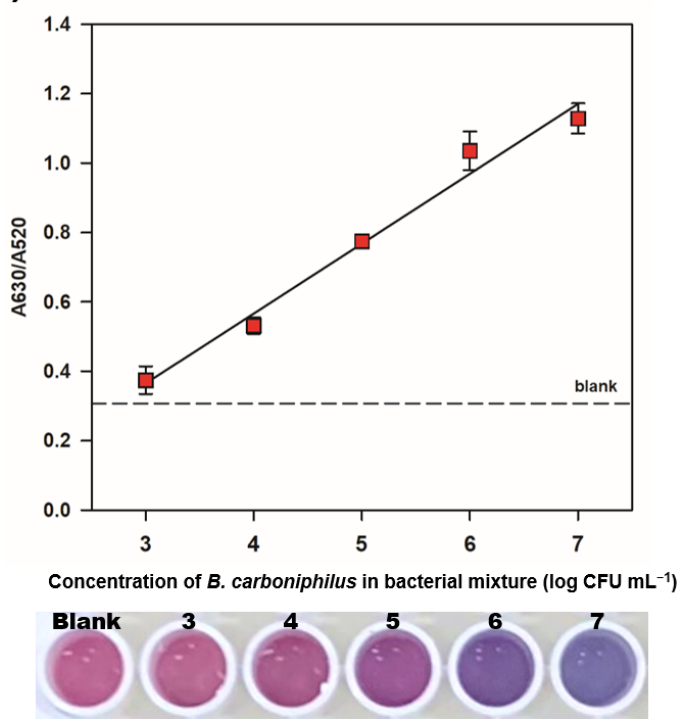

(b)

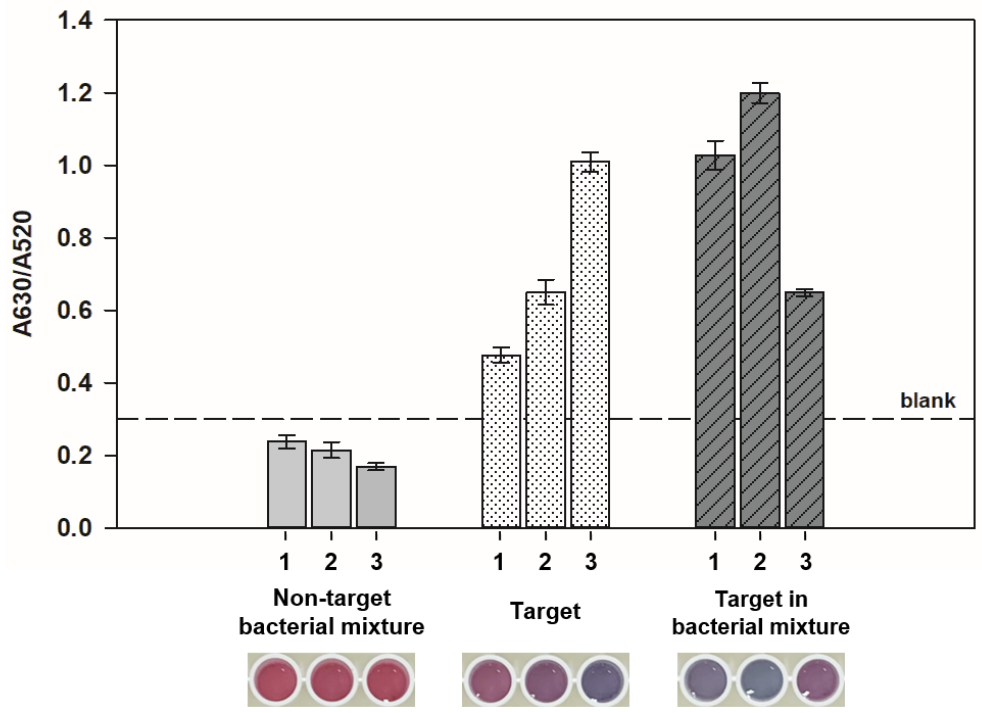

Figure 6. Specific detection of B. carboniphilus in bacterial mixture and biofilm. (a) the detection of the target, B. carboniphilus in bacterial mixture. B. carboniphilus was spiked in the non-target bacterial solution containing B. subtilis, E. coli, E. hermannii, and S. xylosus with each concentration of $5 \log \mathrm{CFU} \mathrm{mL}{ }^{-1}$. The final concentration of $B$. carboniphilus in spiked samples was ranging from 3 to $7 \log \mathrm{CFU} \mathrm{mL} \mathrm{m}^{-1}$. The photograph below shows the color changes of colorimetric aptasensor in different concentrations of the target; (b) the comparison of the A630/A520 values for detecting B. carboniphilus in biofilms by using the colorimetric aptasensor. Three different areas in one biofilm were taken by scrapping in size $1 \mathrm{~cm}$ by $1 \mathrm{~cm}$. The numbers on $X$-axis mean the number of each sample for identification. The photograph below shows the color of the colorimetric aptasensor of each sample. Dots and bars represent means, and error bars denote standard deviations of three measurements.

Further, we tested the reliability of the colorimetric aptasensor by detecting the target in biofilm forms because the samples for diagnosing MIC are usually taken as biofilms. We tested three different types of biofilms; non-target bacterial mixture, target, and target in bacterial mixture (Figure S4). In Figure 6b, all biofilm samples from non-target bacterial mixture showed lower A630/A520 values $(0.238,0.215$, and 0.169$)$ than blank. The A630/A520 values of the target bacterial biofilms ranged from 0.476 to 1.009 , and those of the target in bacterial mixture biofilms ranged from 0.649 to 1.199 . We suspect that these wide ranges of A630/A520 values in samples containing targets resulted from the irregular distribution of bacterial cells in different positions of biofilms. The absorbance ratios of the biofilm samples containing the target bacteria were higher than blank, showing the AuNPs color changes from red to purple or blue, which is the distinguished results from those of the biofilms without the target, B. carboniphilus. The specific detection of the target in bacterial mixture or biofilm suggests that the colorimetric aptasensor would be applicable in real-samples.

There are various methods for testing the presence of microorganisms in samples suspected of MIC. The microscopy method is generally used for determining the overall numbers of microorganisms using a small amount of sample [37]. qPCR method is a molecular microbiological method (MMM) to enumerate microorganisms by amplifying the genetic sequences [38]. However, these methods require expensive instruments and professional knowledge, which are not suitable for field tests. Commercial adenosine triphosphate (ATP) determination kits are also helpful to provide information about the cause of corrosion in the field suspected MIC because ATP presents in all living organisms [39]. However, ATP measurement should be backed up for more specific quantification of the microorganism as all organisms in the pipelines do not associate with MIC. The colorimetric aptasensor, proposed in this study, can effectively complement ATP measurement in the field test for MIC because this aptasensor is available for specific quantification. 


\section{Conclusions}

To date, no conventional or biosensor detection methods are known for B. carboniphilus. This is the first report on the isolation of $B$. carboniphilus-specific aptamers via centrifugationbased partitioning method and their uses for the colorimetric sensor to detect $B$. carboniphilus by employing aptamers mediation on AuNP aggregation leading to blue shifting. The aptamer isolation was based on repetitive centrifugation of unbound oligonucleotides to obtain aptamers with high affinity and specificity. This method does not require repetitive enrichment steps and a large number of target cells to collect aptamers, making it more time- and cost-efficient than SELEX-based methods. One of the isolated B. carboniphilusspecific aptamers (BCA-05) had a dissociation constant of $13.16 \mathrm{nM}$ and high specificity to the target bacteria. We chose this aptamer as a receptor on the two-stage label-free aptasensing platform for detecting B. carboniphilus-based on its ability to protect AuNPs from salt-induced aggregation. The color change of AuNPs that indicated the concentration of the target was expressed in absorbance ratios at 520 and $630 \mathrm{~nm}$ (A630/A520) upon measurement using a UV-VIS spectrometer. In addition, the detection was completed within $40 \mathrm{~min}$ and could be observed with the naked eye. This colorimetric aptasensor showed high specificity with the target and had a linear range from $10^{4}$ to $10^{7} \mathrm{CFU} \mathrm{mL}{ }^{-1}$ with a limit of detection of $5 \times 10^{3} \mathrm{CFU} \mathrm{mL}{ }^{-1}$. Therefore, we intend to demonstrate the relatively quick development of a microbial diagnostic platform for rapidly screening the receptors that respond to the target B. carboniphilus, which have not been reported previously.

Supplementary Materials: The following are available online at https:/ /www.mdpi.com/article/10 $.3390 /$ chemosensors9060121/s1, Table S1: Sequences of the B. carboniphilus-specific aptamers isolated using the centrifugation-based partitioning method. Figure S1: Agarose gel electrophoresis of the final PCR product. Figure S2: Secondary structures of isolated aptamers predicted by the Mfold algorithm. Figure S3: Ultraviolet-visible absorption spectra of AuNPs at each experimental condition: (a) AuNPs only (solid black line); (b) AuNPs without aptamer (black dot line); (c) AuNPs with the BCA-05 aptamer (solid red line); (d) AuNPs with the flow-through solution after BCA-05 binding to B. carboniphilus (red dot line). Additionally, $0.6 \mathrm{M} \mathrm{NaCl}$ was added to $\mathbf{b}, \mathbf{c}$, and d. Figure S4: The formation of artificial biofilms on nutrient agar medium. (a) non-target bacterial mixture biofilm, (b) target bacterial biofilm, and (c) the target in bacterial mixture.

Author Contributions: Conceptualization, B.-C.K.; formal analysis, H.-R.K. and H.-K.K.; investigation, H.-K.K.; methodology, H.-K.K.; resources, S.-J.Y. and K.-B.L.; writing-original draft preparation, H.-K.K.; writing - review and editing, J.K. and B.-C.K.; supervision, B.-C.K. All authors have read and agreed to the published version of the manuscript.

Funding: This work was finally supported by the Korea Institute of Science and Technology (KIST) Institutional Research Program (2E31281 and 2E31371).

Institutional Review Board Statement: Not applicable.

Informed Consent Statement: Not applicable.

Data Availability Statement: All data are included in both the article and Supplementary Material.

Conflicts of Interest: The authors declare no conflict of interest.

\section{References}

1. Fujita, T.; Shida, O.; Takagi, H.; Kunugita, K.; Pankrushina, A.N.; Matsuhashi, M. Description of Bacillus carboniphilus sp. nov. Int. J. Syst. Bacteriol. 1996, 46, 116-118. [CrossRef]

2. Al-Mailem, D.M.; Kansour, M.K.; Radwan, S.S. Moderately thermophilic, hydrocarbonoclastic bacterial communities in Kuwaiti desert soil: Enhanced activity via $\mathrm{Ca}^{2+}$ and dipicolinic acid amendment. Extremophiles 2015, 19, 573-583. [CrossRef] [PubMed]

3. Rahul, K.; Moamongba, K.S.; Rabha, M.; Sivaprasad, V. Identification and characterization of bacteria causing flacherie in mulberry silkworm, Bombyx mori L. J. Crop Weed 2019, 15, 178-181. [CrossRef]

4. Rajasekar, A.; Ponmariappan, S.; Maruthamuthu, S.; Palaniswamy, N. Bacterial Degradation and Corrosion of Naphtha in Transporting Pipeline. Curr. Microbiol. 2007, 55, 374-381. [CrossRef]

5. Rajasekar, A.; Anandkumar, B.; Maruthamuthu, S.; Ting, Y.-P.; Rahman, P.K.S.M. Characterization of corrosive bacterial consortia isolated from petroleum-product-transporting pipelines. Appl. Microbiol. Biotechnol. 2010, 85, 1175-1188. [CrossRef] [PubMed] 
6. Kannan, P.; Kotu, S.P.; Pasman, H.; Vaddiraju, S.; Jayaraman, A.; Mannan, M.S. A systems-based approach for modeling of microbiologically influenced corrosion implemented using static and dynamic Bayesian networks. J. Loss Prev. Process Ind. 2020, 65, 104108. [CrossRef]

7. Ahmed, A.; Rushworth, J.V.; Hirst, N.A.; Millner, P.A. Biosensors for Whole-Cell Bacterial Detection. Clin. Microbiol. Rev. 2014, 27, 631-646. [CrossRef]

8. Templier, V.; Roux, A.; Roupioz, Y.; Livache, T. Ligands for label-free detection of whole bacteria on biosensors: A review. TrAC Trends Anal. Chem. 2016, 79, 71-79. [CrossRef]

9. Altintas, Z.; Akgun, M.; Kokturk, G.; Uludag, Y. A fully automated microfluidic-based electrochemical sensor for real-time bacteria detection. Biosens. Bioelectron. 2018, 100, 541-548. [CrossRef]

10. Otto, M. Bacterial Sensing of Antimicrobial Peptides. Bact. Sens. Signal. 2009, 136-149. [CrossRef]

11. Mahlapuu, M.; Björn, C.; Ekblom, J. Antimicrobial peptides as therapeutic agents: Opportunities and challenges. Crit. Rev. Biotechnol. 2020, 40, 978-992. [CrossRef] [PubMed]

12. Chen, C.H.; Lu, T.K. Development and Challenges of Antimicrobial Peptides for Therapeutic Applications. Antibiotics 2020, 9, 24. [CrossRef] [PubMed]

13. Yasir, M.; Willcox, M.D.P.; Dutta, D. Action of Antimicrobial Peptides against Bacterial Biofilms. Materials 2018, 11, 2468. [CrossRef] [PubMed]

14. Pardoux, E.; Boturyn, D.; Roupioz, Y. Antimicrobial Peptides as Probes in Biosensors Detecting Whole Bacteria: A Review. Molecules 2020, 25, 1998. [CrossRef] [PubMed]

15. Hoyos-Nogués, M.; Gil, F.J.; Mas-Moruno, C. Antimicrobial Peptides: Powerful Biorecognition Elements to Detect Bacteria in Biosensing Technologies. Molecules 2018, 23, 1683. [CrossRef]

16. Pardoux, É.; Roux, A.; Mathey, R.; Boturyn, D.; Roupioz, Y. Antimicrobial peptide arrays for wide spectrum sensing of pathogenic bacteria. Talanta 2019, 203, 322-327. [CrossRef]

17. Kim, H.-S.; Kim, Y.-J.; Chon, J.-W.; Kim, D.-H.; Yim, J.-H.; Kim, H.; Seo, K.-H. Two-stage label-free aptasensing platform for rapid detection of Cronobacter sakazakii in powdered infant formula. Sens. Actuators B Chem. 2017, 239, 94-99. [CrossRef]

18. Wang, T.; Chen, C.; Larcher, L.M.; Barrero, R.A.; Veedu, R.N. Three decades of nucleic acid aptamer technologies: Lessons learned, progress and opportunities on aptamer development. Biotechnol. Adv. 2019, 37, 28-50. [CrossRef] [PubMed]

19. Li, H.; Rothberg, L. Colorimetric detection of DNA sequences based on electrostatic interactions with unmodified gold nanoparticles. Proc. Natl. Acad. Sci. USA 2004, 101, 14036-14039. [CrossRef]

20. Zhang, Y.; Lai, B.S.; Juhas, M. Recent Advances in Aptamer Discovery and Applications. Molecules 2019, 24, 941. [CrossRef]

21. Zhou, J.; Rossi, J. Aptamers as targeted therapeutics: Current potential and challenges. Nat. Rev. Drug Discov. 2017, 16, 181-202. [CrossRef] [PubMed]

22. Tuerk, C.; Gold, L. Systematic evolution of ligands by exponential enrichment: RNA ligands to bacteriophage T4 DNA polymerase. Science 1990, 249, 505-510. [CrossRef] [PubMed]

23. Davydova, A.; Vorobjeva, M.; Pyshnyi, D.; Altman, S.; Vlassov, V.; Venyaminova, A. Aptamers against pathogenic microorganisms. Crit. Rev. Microbiol. 2016, 42, 847-865. [CrossRef] [PubMed]

24. Sola, M.; Menon, A.P.; Moreno, B.; Meraviglia-Crivelli, D.; Soldevilla, M.M.; Cartón-García, F.; Pastor, F. Aptamers Against Live Targets: Is In Vivo SELEX Finally Coming to the Edge? Mol. Ther. Nucleic Acids 2020, 21, 192-204. [CrossRef]

25. Ohuchi, S. Cell-SELEX Technology. Biores. Open Access 2012, 1, 265-272. [CrossRef]

26. Quang, N.N.; Miodek, A.; Cibiel, A.; Ducongé, F. Selection of Aptamers Against Whole Living Cells: From Cell-SELEX to Identification of Biomarkers; Springer: New York, NY, USA, 2017; pp. 253-272. [CrossRef]

27. Kim, H.R.; Song, M.Y.; Chan Kim, B. Rapid isolation of bacteria-specific aptamers with a non-SELEX-based method. Anal. Biochem. 2020, 591, 113542. [CrossRef]

28. Zuker, M. Mfold web server for nucleic acid folding and hybridization prediction. Nucleic Acids Res. 2003, 31, 3406-3415. [CrossRef]

29. Huang, J.; Liu, S.; Zhang, C.; Wang, X.; Pu, J.; Ba, F.; Xue, S.; Ye, H.; Zhao, T.; Li, K.; et al. Programmable and printable Bacillus subtilis biofilms as engineered living materials. Nat. Chem. Biol. 2019, 15, 34-41. [CrossRef]

30. Merritt, J.H.; Kadouri, D.E.; O’Toole, G.A. Growing and Analyzing Static Biofilms. Curr. Protoc. Microbiol. 2005. [CrossRef]

31. Hasegawa, H.; Savory, N.; Abe, K.; Ikebukuro, K. Methods for Improving Aptamer Binding Affinity. Molecules 2016, 21, 421. [CrossRef]

32. Ghisolfi-Nieto, L.; Joseph, G.; Puvion-Dutilleul, F.; Amalric, F.; Bouvet, P. Nucleolin is a Sequence-specific RNA-binding Protein: Characterization of Targets on Pre-ribosomal RNA. J. Mol. Biol. 1996, 260, 34-53. [CrossRef]

33. Pajerski, W.; Ochonska, D.; Brzychczy-Wloch, M.; Indyka, P.; Jarosz, M.; Golda-Cepa, M.; Sojka, Z.; Kotarba, A. Attachment efficiency of gold nanoparticles by Gram-positive and Gram-negative bacterial strains governed by surface charges. J. Nanopart. Res. 2019, 21. [CrossRef]

34. Park, J.-W.; Shumaker-Parry, J.S. Structural Study of Citrate Layers on Gold Nanoparticles: Role of Intermolecular Interactions in Stabilizing Nanoparticles. J. Am. Chem. Soc. 2014, 136, 1907-1921. [CrossRef] [PubMed]

35. Pamies, R.; Cifre, J.G.H.; Espín, V.F.; Collado-González, M.; Baños, F.G.D.; De La Torre, J.G. Aggregation behaviour of gold nanoparticles in saline aqueous media. J. Nanopart. Res. 2014, 16. [CrossRef] 
36. Kim, Y.J.; Kim, H.S.; Chon, J.W.; Kim, D.H.; Hyeon, J.Y.; Seo, K.H. New colorimetric aptasensor for rapid on-site detection of Campylobacter jejuni and Campylobacter coli in chicken carcass samples. Anal. Chim. Acta 2018, 1029, 78-85. [CrossRef] [PubMed]

37. Kannan, P.; Su, S.S.; Mannan, M.S.; Castaneda, H.; Vaddiraju, S. A Review of Characterization and Quantification Tools for Microbiologically Influenced Corrosion in the Oil and Gas Industry: Current and Future Trends. Ind. Eng. Chem. Res. 2018, 57, 13895-13922. [CrossRef]

38. Skovhus, T.L.; Eckert, R.B.; Rodrigues, E. Management and control of microbiologically influenced corrosion (MIC) in the oil and gas industry-Overview and a North Sea case study. J. Biotechnol. 2017, 256, 31-45. [CrossRef]

39. Little, B.J.; Blackwood, D.J.; Hinks, J.; Lauro, F.M.; Marsili, E.; Okamoto, A.; Rice, S.A.; Wade, S.A.; Flemming, H.C. Microbially influenced corrosion-Any progress? Corros. Sci. 2020, 170, 108641. [CrossRef] 